http://dx.doi.org/10.12775/szhf.2019.030

Gintaras KabelKa

Lithuanian Culture Research Institute, Lithuania

E-MAIL: KABELKAG@GMAIL.COM

ORCID: 0000-0002-5307-595X

\title{
The Historiography of Philosophy in Lithuania During Soviet Period
}

\section{Introduction}

In Soviet times, the historiography of philosophy was the most commonly studied philosophical discipline in Lithuania. Alongside the Marxism-based methodological principles considered compulsory for the investigations, there were some cases of using non-Marxist methodology. This article attempts to briefly present the most important research concerning the historiography of philosophy in Lithuania during the Soviet period, to explicate methodological structure displaying the applied elements of philosophical historical explanations. Due to the limit in volume, the article cannot cover all non-Marxist works in the field of the historiography of philosophy, and thus, it is narrowed to one of the pioneers of the field, Romanas Plečkaitis,

This research was funded by a grant (No. LIP-084/2016) from the Research Council of Lithuania. 
whose works will be treated in the context of the applied methodological attitudes of the history of problems.

\section{The Marxist Methodology in Lithuania}

The Marxists investigations of the history of philosophy in Lithuania, can be divided according to:

- structuration of the field of research into discussing a) the static and b) the dynamic elements of the history of philosophy;

- theoretical evaluation into a) emphasizing the relevance of a base, and b) seeking to promote self-sufficiency of a superstructure in regard to the base, i.e. less reducing a theoretical area into a non-theoretical one.

These aspects are related. In Marxism, both static and dynamic elements of the history of philosophy can be treated in terms of their dependence on the base as well as in terms of the inner alterations of the superstructure. One might call the vertical reductionism, i.e. methodological procedure performed by the Marxists who analyze the static segments of the history of philosophy as a product of a social base. The analysis of a philosophical theory not as a self-sufficient value having the cognitive characters of its own but as that having its alleged ground in the "deeper" layers of social reality needs to rest on the so-called level of social base. Such an analysis is called a vertical incision of the historical field.

In fact, vertical reductionism applied to the historiography of philosophy stretches the range of the discipline and is treated as a procedure used in the sociology of knowledge to investigate a theory as a product of social relationships, as a manifestation of the views of a certain social class, i.e. as ideology. When discussing the history of philosophy from this point of view, it appears not as self-alternating historical deployment of theories but as a product of the changes emerging at the base level (change of economical formation). Thus, the analysis of the dynamic factors of the history of philosophy in terms of vertical reductionism is nothing but a mechanical sum of static elements: this procedure does not and cannot embrace the immanent theoretical traits of the development of philosophy, it does not shape its image but, in making 
a vertical incision and analyzing each new philosophical theory as a product of changed social relations of production (in a particular moment in history), it treats each alteration in its development as a static element.

The immanent Marxist analysis of the theoretical plane of the history of philosophy (i.e. the approach that studies the superstructure as a conditionally independent area with regard to its inner properties and alterations) has the least elements of reductionism, a priori typologies, and casual explanations; however, this version of Marxist methodology fails to completely avoid the traits mentioned Here, reductionism shows itself horizontally which means reduction of the research subject not to some non-theoretical (social economical) area but to a phenomenon (Marxism) belonging to the same, i.e. theoretical, level. Horizontal reductionism is a methodological approach that can be called "explanatory solipsism". It enforces the conceptual apparatus of its own theoretical position upon the research subject without considering whether the terms of that apparatus have something in common with the content of the subject. This feature produces ungrounded evaluations and the ignorance of conceptual complexities. Such solipsism originates from exaggeration of the relevance of Marxism considered the only true, most advanced, and most scientific theory which has solved all the possible problems. The key features of this attitude are following:

- the application of a priori evaluations that are based only on their own self-estimation to philosophical theories of the past: whichever theory would be discussed, one knows a priori that it has not yet "matured" to Marxism and that its problems have already been perfectly solved by scientific Communism, scientific materialism, and whatever synonyms of Marxism are used;

- the deficiency of the conceptual apparatus of the theoretical position (Marxism) applied to the evaluations of the theories discussed: often the research subject is conceptually much richer than Marxism for it embraces the problems that Marxism does not even investigate, or solves the same problems on the ground of different suppositions, or pursues different cognitive goals, or has more copious terminology, etc.; some instances of vertical and horizontal reductionism in the investigations of the Lithuanian history of philosophy will be briefly introduced further. 
The Marxists who performed vertical reduction estimated a chosen philosophical theory according to a social class its author (or a group of authors) represented and the period of history (i.e. social economical formation) they lived in. In Lithuanian historiography of philosophy this procedure was most often applied by Antanas Gaidys and the group of researchers he supervised. The value of a theory (or its part) was estimated with reference to the said social biographical fact. Such reductionism considers philosophy as a consequence of social relations and almost completely eliminates its self-estimated value from a historical explanation. In this case, philosophy is considered an ideology and, instead of an inquiry into history of philosophy, a critique of ideology is conducted ${ }^{1}$. Then sociological research on the class differentiation of the thinkers in the Lithuanian diaspora, which is meant to justify the estimations of philosophical theories, is performed. The operations convey the principle of the Marxist methodology. In the work discussed, one finds particularly strong illustrations of this principle. In addition to a usual indication of the class position of philosophers, a motive of "social engagement" is used: the members of the diaspora not only express their class concerns but also fulfill the orders issued by "private companies and reactionary organizations". Reductionism also transforms a real subject of inquiry into a social one, i.e. into what Marxism cares about and what can be treated as an ideology. The fact that the problems discussed might have nothing to do with social questions is completely disregarded. "[In Neo-Thomism G. K.], the discussion of the real philosophical problems is subjected to an apology of religion, and even, in the most cases, of capitalism. [...] From the Marxists point of view, one must seek for the meaning of life in the life itself, in its revolutionary reformation and not beyond it"2. Hence, all the problems philosophy deals with (such as the meaning of life, the norms of morality and even the existence of God) are tackled not by theoretical but by practical means of revolutionary reformation. Therefore, there is no need to evaluate them theoretically. Hence, what is examined here is non-Marxist philosophy that exists after Marx and therefore cannot be evaluated by the proponents

1 See Antanas Gaidys, "Pagrindinès idealistinès filosofijos kryptys", in: Antanas Gaidys, Ideologinés srovés lietuvių išeivijoje (Vilnius: Mintis, 1978), 167-279.

2 Ibidem, 175, 191. 
of Marxism otherwise as a blind lead or a dead-end of thought. They constantly mention a crisis of contemporary bourgeois philosophy in general and of the philosophy of the diaspora in particular: by sticking to its erroneous ideological premises this philosophy is doomed to never reach the truth, to forever stray along its own wrong paths and to eventually vanish confused and prostrated with its own faults.

The doctoral thesis by Brone Leskauskaite is one more example of vertical reductionism. Here, the author fights against an adversarial ideology - Catholic philosophy of Aleksandras Jakštas-Dambrauskas.

In analysing the origins of Materialism and Marxism in Lithuania, one cannot ignore the bourgeois philosophy, "the thoughts of the ruling class". The philosophy of Catholicism was such a thought. [...]. One can scientifically elucidate the views of Aleksandras Dambrauskas-Jakštas only by using the Marxist-Leninist methodology, examining them as a reflection of the certain reality, which has been determined by class position. In order to achieve this goal it is necessary to deduce the social-economical conditions [...], which has determined his class interests ${ }^{3}$.

Apart from the principle of partisanship, here the category of a "worldview" is used, which allows treating the problems in question in terms of class struggle. This category renders the theory under investigation a part of the personal views which, in turn, depend on a persons' class position. Hence, the proletariat world-view must comprise only the Marxist ideas and values, and the middle and higher classes world-view - of all the other theories. So, the truth or falsity of a philosophical theory is predetermined: one can evaluate a thinker's future theories in the very moment of his (or her) birth. This attitude is disproved by the fact that the creators of the proletariat worldview were themselves far from being representative of the exploitative classes. Thus the research subject is contextualised not at the theoretical problematic level (when philosophical conceptions influencing the origination of a theory are ascertained) but at the practical level, where the factors grounding a world-view are reconstructed. The explanation of a theory thus turns into

${ }^{3}$ Bronè Leskauskaitè, "Aleksandro Dambrausko-Adomo Jakšto visuomeninès filosofinès pažiūros”. Doctoral dissertation (manuscript). (Vilnius: Institute of History, 1975), 6, 7, 18. 
a tendentious fixation of the empirical facts of social reality in a certain period of history, and its prejudiced description. Research in the history of philosophy becomes an ideologically informed analysis of the history of society (an explanation of philosophical texts is replaced by sociological research), which is intended to put one world-view against another and to fight against bourgeoisie.

Marxist researchers (Zenonas Burnys, Vytautas Pikutis, Leonardas Zasimauskas, and al.) who applied reductionism both vertically and horizontally should be mentioned here. In his thesis, Pikutis emphasized the relevance of the history of philosophy to ideological education of contemporary society, examined the social and ideological background of Stasys Šalkauskis views, and referred 1 to the numerous biographical and social facts ${ }^{4}$. Here, Šalkauskis' philosophy is analyzed also at the theoretical level, and placed mostly within $\mathrm{f}$ the Marxist categories; thus the weakness of the very research subject is shown. Burnys explains religion and morality on the grounds of the Marxist classics' principles which identify the place of religion and morality in social processes: "the roots of religion lie in contradictory and alienated traits of antagonistic social being"5. In other words, religion and morality are treated as phenomena of the superstructure dependent on the base, as the forms of ideology. Such an analysis is grounded on vertical reductionism. Here the Marxists categories are imposed on the research subject: one of the research goals is "to evaluate the position of the representatives of Catholic ethics from the positions of scientific ethics"6. By the latter operation, a priori known evaluations are determined, e.g. "the Idealist interpretation of a social process is weak, abstract, and utopian; [...] morality cannot overcome antagonistic contradictions, for they are grounded on exploitation"7, and so on. The aforementioned traits of both kinds of reductionism are characteristic of this research.

4 See Vytautas Pikutis, "Stasio Šalkauskio filosofinès pažiūros". Doctoral dissertation (manuscript). (Vilnius: Vilnius University, 1974).

5 Burnis Zenonas, "Katolicheskaya etika v Litve v 1920-1940 gody”. Doctoral dissertation (manuscript). (Vilnius: Vilnius University, 1983), 3.

6 Ibidem, 5.

7 Ibidem, 23. 
In Albinas Lozuraitis' investigations of Ancient philosophy, one must differentiate between two levels: that of declared theoretical principles, and that of the methodological structure of actual research. The first ones are thoroughly laid out in the beginning of his book, Truth and Value (1980). First, the author underlines the aspects of history and continuity in the philosophical problems ${ }^{8}$. Then the researcher emphasizes the necessity of revealing the genesis of philosophical problems treating it, however, as the determination of the relation between cause and effect ${ }^{9}$. The historian of philosophy also refuses to impose the schemes of a priori evaluation on the research subject, and advocates its singularity while emphasizing the historical necessity of the stages of the development of philosophy ${ }^{10}$. By renouncement of these propositions prevailing in Marxism, its very striving for the evaluation of past theories by means of its own theory is (at least theoretically) eliminated. At the same time, Lozuraitis emphasizes the principle of historicism, which affirms objectivity of the historical investigation (i.e. the evaluation of the research subject by the measure of its times); however, he states that pure objectivity is in fact an ideal unlikely to reach ${ }^{11}$. On the other hand, the historian does not refute the finality of the historical process, which implies the perfection of the final end. This controversy involves such problematic moments as:

- the explicative solipsism in the evaluation of dynamic aspects of the history of philosophy is minimized: the development of philosophy which is not represented as a chain of errors which leads toward Marxism;

- the problem of compatibility between historicism and the principle of finality which arises: if the Marxist historian of philosophy renounces his own methodological schemes and categories and emphasizes only the principle of historicism, then his methodology loses its particularity and becomes merely that of historicism.

Lozuraitis himself notices this contradiction and proposes the way to solve it explaining the development of philosophy be means of the Hegelian dialectics of contradictions ${ }^{12}$. Lozuraitis' theoretical methodological principles

\footnotetext{
${ }^{8}$ See Albinas Lozuraitis, Tiesa ir vertybe (Vilnius: Mintis, 1980), 6.

9 Ibidem, 8.

10 Ibidem, 10.

11 Ibidem, 13.

12 Ibidem, 33.
} 
allow considering him the only consistent Hegelian among Lithuanian Marxist historians of philosophy who emphasize the aspect of theoretical finality in the conception of the development of philosophy. Furthermore, the notion of "contemporary thought" he uses is much broader than Marxism. To be a Hegelian in the camp of Marxism means to affirm the independence of the superstructure and base (in philosophy as well), i.e. to reveal certain immanent regularity in the development of philosophy, or, in terms of Marxism, to emphasize a relative self-sufficiency of philosophy.

Unfortunately, there are very few Hegelian aspects in Lozuraitis' practice of current research (there are some evaluations of past theories with regard to historical conditionality, i.e. to the level of their historical development). It is dominated by the Marxist conception of dependence of philosophy on practical activity (vertical reductionism):

It is possible to understand the thought of the past only by tracing its relation to human beings' material living conditions. [...] The opposition between value and truth could not be overcome philosophically, for it had the objective roots - it was grounded in human being's social antagonism. [...] The development of philosophy when examined in regard to practice loses its occasional character and regains regularity based on the material living conditions of society $^{13}$.

The researcher also gives a lot of attention to unfolding the social economic structures of the examined period of history. He combines the philosophical principle of practical conditionality with explications of self-sustaining forces of philosophy. In his investigations, the accentuated concept of development based on the mentioned "material living conditions of society" gains the base-alteration content.

Lozuraitis explains philosophical theories as products of a certain period of history, at the same time seeking to connect these theories to the social forces as closely as possible - to interpret them as an expression of these forces. Sometimes he goes far enough to treat certain thoughts of a classical philosopher (that are generally treated by various methodologies and approaches in the history of philosophy as independent from the context

13 Lozuraitis, Tiesa ir vertybè, 54, 186-187. 
of their origin, not as expressing a certain period of history but as forming it) merely as a reflection of social reality of a period. In this case, the direction of the causal relationship between a classic and his living context, which dominates the historiography of philosophy, is changed. By reducing philosophy to the level of social forces Lozuraitis particularly emphasizes the relevance of the category of practice openly denying at the same time one of the key methodological principles of Marxism - the partisanship of philosophy, i.e. the view on philosophy as an expression of the class struggle. "However, it would be inaccurate to qualify Ancient philosophy as a world-view of the slaveholder's class or even of free Ancient people. The world-view of a certain period of history is too wide to become a property of a class. It is based on an objective ground - practical life of human beings not coinciding with the living conditions of some class"14.

Lozuraitis depicts the history of philosophy as a "ladder": philosophical thought dialectically progresses ascending to higher steps, and each of the higher embraces and enriches the lower ones. Philosophy does not move upwards continuously: it lingers for a while on some step and then, when the changes in the material living conditions of a society ripen (or when one economic formation replaces other), there arises the possibility to suddenly jump to a higher step. Thus, the development of philosophy is depicted as progressing not consecutively but by certain revolutionary ruptures. "The beginning of the Ancient Greek philosophy, its emerging from a primitive word-view, from mythology", being "a real breakthrough in a history of thought"15 is conceived as the first "leap" into a higher stage. Hence the work analyzed covers only one - ancient - period of philosophy, other stages remain implicit. The highest step of this "ladder" - Marxism - as it was pointed out, together with the intrinsic dynamics of the whole development of philosophy (without already mentioned material living conditions) was settled as the quest for the unity of epistemological and social philosophical questions, of truth and value, which becomes possible when thought embraces practice ${ }^{16}$. The image of the history of philosophy envisaged by Lozuraitis shows philosophy not

\footnotetext{
14 Ibidem, 37.

15 Ibidem, 34.

16 Ibidem, 17.
} 
merely mechanically (cumulatively) improving but solving concrete contradictions in its path of progress. At the same time, this image is characteristic of the underlying ambivalence: pre-Marxist philosophy, while climbing continually up the "ladder" of history, is conditioned by prevailing social antagonism and therefore cannot adequately conceive reality unless it becomes the Marxist reality.

The methodological structure of the research in the history of Lithuanian aesthetics done by Juozas Mureika is not heterogeneous. The examples illustrating vertical reductionism applied by Mureika are the following: the development of aesthetics is explained by class struggle ("the social class structure of the population of Lithuania influenced, however indirectly, the development of aesthetic culture and thought" ${ }^{\prime 17}$; the social cultural context of the research subject - the cultural life in Lithuania of the first half of the $20^{\text {th }}$ century - is interpreted as the dominance of bourgeois ideology $y^{18}$; in explaining the cultural processes the author refers to Lenin's theory of formation of bourgeois nations; the biographical facts from the thinkers' lives are used widely over the work, theories of aesthetics are used to explain their social statuses; theoretical problematical factors are treated as manifestations of ideology ("in aesthetics, the struggle between Materialism and Idealism shows itself as [...] essential incompatibility between the Socialist and bourgeois ideologies"19). Here vertical reductionism is not a prevalent but an auxiliary methodological operation.

The researcher also applies horizontal reductionism when comparing the research subject to Marxism as to the most truthful theoretical position, both at the level of the problem formulation and at that of the obtained results. Here, average explanatory solipsism prevails: although the Marxist ways of solving the problems of aesthetics are considered to be the only true and indubitable, the results obtained by the theories under investigation are estimated not in a radical nihilistic way but their shaping is treated as determined by the use of imperfect theoretical tools. Such tools (the elements of a theoretician's world-view, which are determined by the social cultural

\footnotetext{
17 Juozas Mureika, Lietuvių materialistine estetika 1900-1940 (Vilnius: Mintis, 1981), 28.

18 Ibidem, 11-33.

19 Ibidem, 38.
} 
context, his (or her) chosen philosophical school, the suppositions and the way of solving a particular problems of aesthetics) one tries to reconstruct (and not to qualify in advance as false without going deeper into their particularity) applying another aspect of research - a methodological approach. This approach is intertwined with the methodological operations indicated above, but, at the same time, it is a distinctive attitude of research in the context of entire Marxist historiography of philosophy. Mureika links closely the methodology of philosophy with so-called "solution of the main philosophical question", and considers the ways in which the question can be solved (paradigms) - Materialism and Idealism - "methodological direction" ${ }^{20}$. In other words, these theoretical directions which Marxism considers are primarily treated as the ground of all the rules of doing philosophy, the ground that has to be found and explicated in order to obtain the adequate understanding of the overall structure of the research subject.

In the Lithuanian historiography of philosophy, there are some Marxist investigations for which the label of explanatory solipsism is invalid. Such are the works by Feliksas Mačianskas ${ }^{21}$ and Edvardas Kriščiūnas ${ }^{22}$. These works are united by a common area of the history of philosophy: they investigate the very history of Marxism. In this instance the research subject and the estimated position are the same - Marxism, therefore explanatory solipsism is invalid. If, instead of this attitude, one would choose the category of criticism, radical difference between these works will be realized. Although they both were written in the late Soviet period, when a possibility of free enunciation of estimations emerged, the first one (by Mačianskas) can be considered a panegyric of the genre of history of the Communist party (dozens of similar works were fabricated during the Soviet times, and this work is mentioned here only because it belongs to the historiography of philosophy), and the second one (the thesis by Kriščiūnas) is a critical analysis of the history of Marxism in Lithuania.

20 Ibidem, 9.

${ }^{21}$ See Feliksas Mačianskas, Visuomeninès V. Kapsuko pažiūros (Vilnius: Mintis, 1987).

22 See Edvardas Krishchyunas, "Marksistkaya teoriya obshchestvennogo razvitiya v Litve 1917-1940". Doctoral dissertation (manuscript). (Vilnius: Lithuanian Institute of Philosophy, Sociology and Law, 1985). 


\section{The History of Problems}

Plečkaitis was a pioneer of the Lithuanian research on the history and historiography of philosophy as an independent philosophical discipline in Lithuania. His writings had a significant impact on the majority of Lithuanian historians of philosophy, which led to appearance of a certain research paradigm. It should be noted that Plečkaitis, like many other historians of philosophy, applied research methodology that is not explicated and operates implicitly. We argue that research by Plečkaitis is attributable to the methodology of the history of problems.

These fundamental methodological elements of the history of problems function in Plečkaitis's inner history structure: the history of philosophy as the history of discovery and settlement of problems (or change of problematic situations), treatment, and a historical reconstruction of the problematic situations in preference of objective historical understanding, an image of progressive philosophy development. These principles are supplemented by the methodology of actualization - rational reconstruction - elements that enrich the historic problematic research by establishing links between the past and contemporary philosophizing. There are not metaphysical implications for neo-Kantian tradition of the history of problems in Plečkaitis works: they are focused on cognition of the history of philosophy, not on deliberations of its ontological status. Plečkaitis structures the researched substance on the basis of the problematic access: the object of study is a philosophical theory considered as results of discovery and solution of problems. In applying this access, a problem is a basic structural unit of the history of the philosophy ${ }^{23}$, i.e. the specific questions given to the philosophers by the tradition and the results they obtained, which in turn leads to the possibility to give new answers or the need to raise new questions (to discover new problems). This issue includes the problematic situation and specific theory that it produces as the result of the problem.

${ }^{23}$ See Ingeborg Heidemann, "Die Philosophie Nicolai Hartmanns im Aspekt der Probleme", in: Nicolai Hartmann, Der philosophische Gedanke und seine Geschichte (Stuttgart: Reclam, 1977), 190. 
The most important methodological procedure of Plečkaitis research is historical reconstruction of a problematic situation ${ }^{24}$ : it is the methodological core of this researcher's works around which secondary, complementary elements that supplement philosophical historical interpretation of the problems are supplemented. This study follows directly from the principle of philosophy as the whole concept of problems: current theories are treated as result of new or old problems (process of theoretizing, the final point) and in order to explain their origin, we need to refer to the starting point - the constellations of philosophical ideas that led to different process of theoretizing. The most important development tool in the reconstruction of problematic situations is complex genetic interpretation of a theory, i.e. the problematic level. Its aim is to restore the problematic context of a researched theory (solved problem), composed of the same results of previous problems, also to indicate the innovative elements of this theory (cognitive value).

Plečkaitis's research usually reconstructs two problematic situations: the first one could be described as central or global - constellations of the theoretical elements that formed in Western philosophy, the prevailing problems of the time; the second problematic situation is peripheral or localized - a theoretical situation is in a peripheral context (in this case - Lithuania). Central and peripheral contexts are linked by cause and effect relationship (the first set of elements determine the appearance of the second set of elements), but this dependence is not absolute: the context of peripheral partial autonomy presents reconstructed peripheral problematic situation in which, near the central theories, there are also local context-specific problem constellations that are characteristic only to it. The fact that a single problematic situation can be reconstructed in the peripheral context shows that the emerging problems are effected not only by the central problematic situation, but also the local constellation of ideas (competition of theories).

In the literature dealing with contextual interpretation, there are often limited views to provide peripheral context dependence from the center: it is determined which statements of theories of individual context or principles

24 See Romanas Plečkaitis, Feodalizmo laikotarpio filosofija Lietuvoje: Filosofija Lietuvos mokyklose XVI-XVIII amžiais (Vilnius: Mintis, 1975), 62-68, 75-83, 85-94, 95-111, 124-135, $148-154$, etc. 
are derived from general philosophy and which are different from it. In this research, the theories of the past are treated as separated "private" entities (atoms), separate or connected by similar or different statements. Discoveries or solutions to problems of peripheral context are understood as an integrated entirety. However in the research under discussion, as mentioned, the object of study is treated as a fragment of permanent universal process of discovering and solving problems, potentially linked to a number of previously defined theories or coexisting theories-competitors. Those two problematic situations, directly related with each other, existing in one historical period form a "horizontal" (simultaneous) level of the problematic reconstruction. In Plečkaitis's research it is often a problematic situation in the medieval philosophy. It is complemented by the "vertical" level, which means that problematic situations of the earlier periods of history of philosophy (ancient, early medieval) were philosophical issues developed by the medieval philosophers. Thus, the historical reconstruction of the reconstructed problematic situations involves at least of three levels, and considers problematic situations of ancient, medieval (different periods are treated as the whole entirety) European and medieval philosophy in Lithuania. The reconstruction of the central problematic situation that consists of levels of solutions of several historical periods, results in a very broad explanatory context of the subject studied (Lithuanian philosophical theories) - it implicitly includes the ancient philosophy and entirety of different medieval theoretical ways (using rational reconstruction - modern philosophy as well). In other words, the interpretative element is included in the broad communication contextual network establishing its links with the very remote theoretical elements. Usually, contextual interpretations are limited by indication of contextual elements of the researched object (in case of provincial philosophy - research on reception, theories of general philosophy). Studies in the history of problems by Plečkaitis that directly analyze Lithuanian philosophy implicitly consider the history of general philosophy: the central problematic situation is constructed from several different periods of problematic levels, genetic research is made of this theory of philosophy, which led to the emergence of identification of problematic conditions.

The chosen so-called objective historical understanding access implies the philosophy, as generally valid, objective knowledge of the structure of the 
concept. This means that, from interpretation of emergence of the theory of philosophy, subjective and trans-theoretical factors are eliminated: philosophy is not regarded as an expression of existential aspirations, mystical experience, and other subjective factors instrumental to the practical activities of the thinker or the like. It is rather regarded as an objective independent theoretical framework that was formed in discovering and solving the problems identified in accordance with the received conditions for solutions (the original problematic situation).

Since philosophy is treated as the entirety of discovery and solution of the specific problems, its evolution is portrayed as a permanent (not always consistent, with some declines or exceptional changes) quantitative and qualitative growth of this entirety - hence, progressivist image of its development functions in presentation of the history of problems An access of objective historical understanding, since the dissociation from trans-theoretical factors (which are basically non-historical - beyond the conditions of the historical context) which is the researched item is treated as a product of a specific historical (problematic) situation that is portrayed as a static element in the history of philosophy as a whole. A dynamic factor in the structure of contextual interpretation arises when these static elements are related to the broader entirety, taught in the historical time line. An interpretation of progressive development philosophy is based on the structure of the problematic situation: according to constellation of the problems solutions of the previous results a new solution to problems is obtained (or a new problem is discovered) which, in turn, becomes the starting point for subsequent decisions, etc. Thus, a separate theory, as the result of the problem solution inevitably presents new data, i.e. is more advanced with respect to its predecessors. A clearly implicit assumption lies in this structure that the "defective" theories - those that are inferior to their predecessor and do not produce any new problematic situation - automatically "drop out of the game", are forgotten and are not addressed by the historians of philosophy, they research only productive decisions. Consequently, this the development of philosophy, contemporary awareness level is considered to be the most advanced - it is considered that our solutions of the problems have the richest (i.e. the richest and most valuable heuristically) conceptual measures which have been accumulated during the development of philosophy (this assumption functions when the 
history of problems is added by the elements of rational reconstruction). The above model of development of philosophy resulting from the problematic situations appears at first glance to be purely cumulative: the development of knowledge is consistent when awareness of entirety is added by new statements, this development is continuous, it highlights a more quantitative growth rather than qualitative changes. However, progressive image functioning in the works by Plečkaitis is based on revolutionary fractures of the history of philosophy - a paradigm change: this modern interpretation element of the history of science, cumulative development model taken from neo-Kantians is supplemented by the emphasis on qualitative changes. Examples of such fractures in Plečkaitis studies: the down-fall of the scholastic philosophy and the spread of the philosophy of Modern times, Enlightenment thinking embeddings ${ }^{25}$ and the like. Since the problematic situations include the poles of center of the peripheral context, thus also portraying the significant changes of development of philosophy, changes of central problematic situation have crucial importance: when they occur, a localized problematic situation inevitably changes (peripheral changes cannot lead to paradigm shifts). A radical change of solutions to problems (paradigm shift) methodology of the history of problems presents an emergence of a completely new problematic situation, the problematic situation is treated as a paradigm effecting all the remaining problems: the constellation of such elements, which support a single mode of philosophizing (paradigm).

Thus, the element of revolutionary fracture of the development of philosophy is not external to history of problems, artificially imposed to it, even though a paradigm change in the classical version of the methodology does not function (it consists of a "spiral" development image of rises and falls) In this case, it is demonstrated with the methodological tools - during the reconstruction of the mentioned paradigmatic, revolutionary problematic situation. The paradigm change is seen apart from the extreme variations of interpretation in the existing methodology of the history of science which state incommensurability in different paradigms: in Plečkaitis works in addition to new ways of solving problems, problematic continuity is also marked. It is shown what the new philosophizing inherited from the old one.

25 See ibidem, 208-211, 273-306, etc. 
A theoretical version of the methodology of the history of problems formulated by Nicolai Hartmann and practical functioning of its elements differ in Plečkaitis's studies in such a way that the latter case of the abovementioned problematic situation includes the elements that are external to philosophy - scientific and technical progress, economic factors, and so on. The traditional version of this methodology explains the development of philosophy only with the help of immanent elements. This means that the development of philosophy is treated as dependent on science (nature studies) and related factors (technical innovation, etc.), progress as its derivative. This reducing interpretation process leads to the access application of the abovementioned objective historical understanding: it treats philosophy as a part of general scientific knowledge, subordinate to the same rules of thinking. If science is driven not only by internal problems, but also the needs of empirical reality, the same effects are thus characteristic to philosophy.

Plečkaitis represents philosophy development, understood as an objective system of knowledge as controlled by the same process, as science in general. Changes in scientific knowledge lead to changes in philosophy as one of the areas of that knowledge: science and philosophy in the broad sense are causally linked. This reduction method of imaging of the development of philosophy minimizes the autonomy of philosophical thinking (if this way of thinking is interpreted as different from science). On the other hand, it helps in the interpretation of the history of philosophy to eliminate unexplained objective factors (or other subjective ones) and speculatively attribute the metaphysical context. In Plečkaitis's writings, history of philosophy is not a non-historical gallery of unique personalities creation or development of theories of incomprehensible force. It is a development of objectively emerging ways of thinking and the output of it, the objectives - efficient, capable of providing practical benefits to society and enriching the cultural consciousness of knowing.

\section{Conclusions}

The Marxist methodology In Lithuania structures the field of inquiry by means of vertical and horizontal reduction. The first one is founded on the 
causal relations between the basis and the superstructure, the second - on the application of Marxist categories. So-called interpretative solipsism is characteristic to the latter methodological procedure. There are different degrees of interpretative solipsism in the Lithuanian history of philosophy. Lozuraitis and Mureika regard Marxism as quite a reliable method for solving some theoretical problems. Their approach is akin to the methodology of the history of problems. In Marxist methodology, the analysis of static elements of history is dominating. It considers the dynamic factors as secondary and tries to elaborate the concept of development of philosophy towards Marxism.

The most important elements of Plečkaitis research are: the concept of the history of philosophy as a process of philosophical problems transformation which initiates the historical study and provides the material and the structures of the interpretation of the results; the historical reconstruction of a problematic situation as a constellation of theoretical elements motivating the creation of a new theory, the objective historical understanding which treats philosophy as the totality of objectively and universally functioning cognitional elements and excludes all subjective and metaphysical factors from the interpretation of the history of philosophy.

Progressive image functioning in the works by Plečkaitis is based on revolutionary fractures of the history of philosophy - a paradigm change. A radical change (paradigm shift) is presented as an emergence of a completely new problematic situation. A problematic situation is treated as a paradigm effecting all the remaining problems: as the constellation of such elements, which support a single mode of philosophizing (paradigm). In Plečkaitis works in addition to new ways of solving, problems, problematic continuity is also marked. It is shown what the new philosophizing inherited from the old one.

\section{Bibliography}

Gaidys Antanas. 1978. "Pagrindinès idealistinès filosofijos kryptys”. In: Antanas Gaidys, Ideologinès srovés lietuviu išeivijoje. 167-279. Vilnius: Mintis.

Heidemann Ingeborg. 1977. "Die Philosophie Nicolai Hartmanns im Aspekt der Probleme". In: Nicolai Hartmann, Der philosophische Gedanke und seine Geschichte, 187-199. Stuttgart: Reclam. 
Leskauskaitė Bronė. 1975. "Aleksandro Dambrausko-Adomo Jakšto visuomeninès filosofinès pažiūros”. Doctoral dissertation (manuscript). Vilnius: Institute of History.

Lozuraitis Albinas. 1980. Tiesa ir vertybe. Vilnius: Mintis.

Mačianskas Feliksas. 1987. Visuomeninès V. Kapsuko pažiūros. Vilnius: Mintis.

Mureika Juozas. 1981. Lietuviu materialistine estetika 1900-1940. Vilnius: Mintis.

Pikutis Vytautas. 1974. "Stasio Šalkauskio filosofinès pažiūros". Doctoral dissertation (manuscript). Vilnius: Vilnius University.

Plečkaitis Romanas. 1975. Feodalizmo laikotarpio filosofija Lietuvoje: Filosofija Lietuvos mokyklose XVI-XVIII amžiais. Vilnius: Mintis.

Burnis Zenonas. 1983. "Katolicheskaya etika v Litve v 1920-1940 gody”. Doctoral dissertation (manuscript). Vilnius: Vilnius University.

Krishchyunas Edvardas. 1985. "Marksistkaya teoriya obshchestvennogo razvitiya v Litve 1917-1940". Doctoral dissertation (manuscript). Vilnius: Lithuanian Institute of Philosophy, Sociology and Law.

\begin{abstract}
This article attempts to briefly present the most important research in the historiography of philosophy in Lithuania during the Soviet period, to explicate their methodological structure displaying the applied elements of philosophical historical explanations. The Marxist methodology In Lithuania structures the field of inquiry by means of vertical and horizontal reductions. The first one is founded on the causal relations between the basis and the superstructure, the second - on the application of the Marxist categories. Alongside the Marxism-based methodological principles considered compulsory for the investigations, there were some instances of using non-Marxist methodology. R. Plečkaitis's works will be treated in terms of the applied methodological approach to the history of problems. The most important element of his research is the historical reconstruction of a problematic situation as a constellation of theoretical elements motivating the creation of a new theory.
\end{abstract}

Keywords: Lithuanian philosophy; historiography of philosophy; Marxist methodology; historical re construction; problematic situation 